\title{
Pendidikan Agama Kristen dan Tuntutan Kualitas Sumber Daya Manusia Menghadapi Persaingan Masyarakat Global
}

\author{
Ahmad Tabrani \\ Sekolah Tinggi Agama Kristen Terpadu Pesat \\ Email:ahmadstakpesat@gmail.com \\ Ida Destariana Harefa \\ Sekolah Tinggi Agama Kristen Terpadu Pesat \\ Email: idadestariana01harefa@gmail.com
}

\begin{abstract}
This research was conducted using a literature study method by conducting a literature review that fully sought literature sources such as books, research journals related to the research topic and several articles and news sources. The analysis is presented descriptively to discuss the condition of Indonesia's human resources in the midst of changing times and how Christian education can contribute to build innovative human resources. The conclusion is that Christian education not only emphasizes Christian dogmas, but must be able to bring students to understand their vocation and role in society. Christian education not only shapes the character of students, but must develop the potential in students. This can be done if educators see and threat students as individuals who have large amount of potential to be discovered, gratefull for and developed. The learning process that is indoctrination must begin to be abandoned and replaced with a learning process that helps students to search and find knowledge. Christian education that applies an empowering learning process by training highlevel thinking patterns where the thinking process is analytical, evaluative and creative thinking. This students are prepared to have the ability to innovate.
\end{abstract}

Keywords: Christian Religious Education; Human Resoursces; Global Challenges.

\begin{abstract}
Abstrak
Penelitian ini dilakukan dengan metode studi literatur dengan melakukan kajian pustaka yang sepenuhnya mencari sumber-sumber literatur seperti buku-buku, jurnal-jurnal hasil penelitian yang berkaitan dengan topik penelitian dan beberapa artikel serta sumber berita. Analisis disajikan secara deskriptif untuk membahas kondisi sumber daya manusia Indonesia di tengah perubahan zaman dan bagaimana pendidikan agama Kristen dapat berkontribusi dalam membangun sumber daya manusia yang inovatif. Diperoleh kesimpulan bahwa Pendidikan Agama Kristen bukan hanya menekankan dogma-dogma keKristenan, namun harus mampu membawa peserta didik memahami panggilan dan perannya di tengah masyarakat. Pendidikan Agama Kristen bukan hanya membentuk karakter peserta didik, namun harus mengembangkan potensi dalam diri peserta didik. Hal ini dapat dilakukan jika para pendidik melihat dan memperlakukan peserta didik sebagai pribadi yang memiliki sejumlah besar potensi untuk ditemukan, disyukuri dan dikembangkan. Proses pembelajaran yang bersifat indoktrinasi harus mulai ditinggalkan dan digantikan dengan proses pembelajaran
\end{abstract}


yang menolong peserta didik untuk melakukan proses pencarian dan penemuan pengetahuan. Pendidikan agama Kristen yang menerapkan proses pembelajaran yang memberdayakan dengan melatih pola berpikir tingkat tinggi, yaitu proses berpikir analisis, evaluatif dan kreatif thinking. Dengan demikian peserta didik disiapkan untuk memiliki kemampuan melakukan inovasi.

Kata-kata Kunci: Pendidikan Agama Kristen; Sumber Daya Manusia; Tantangan Global.

\section{PENDAHULUAN}

Kualitas sumber daya manusia dalam suatu bangsa memberi pengaruh besar bagi kemajuan bangsa tersebut. Karena kemajuan suatu bangsa selalu dimulai dengan terjadinya perubahan dalam masyarakatnya. Perubahan dalam masyarakat didahului dengan perubahan cara berpikir yang menentukan kualitas sumber daya manusianya. Peningkatan kualitas sumber daya manusia dipengaruhi oleh upaya peningkatan taraf pendidikan masyarakat baik yang bersifat informal, formal maupun non formal (Madjid, 1987, 33-34). Di samping pengaruh lingkungan keluarga, pembentukan karakter, wawasan dan kepekaan seseorang terhadap permasalahan sosial dalam masyarakat dipengaruhi oleh pendidikan formal yang ditempuhnya. Sistem pendidikan formal sendiri menjadi sangat penting perannya karena berfungsi sebagai mekanisme institusional yang memberi pengaruh penting dalam mengembangkan keterampilan dan pengetahuan seseorang (Todaro, 1983, 434).
Pendidikan didefinisikan sebagai usaha sadar dan terencana untuk mewujudkan suasana belajar dan proses pembelajaran agar peserta didik secara aktif mengembangkan potensi dirinya untuk memiliki kekuatan spiritual, pengendalian diri, kepribadian, kecerdasan, akhlak mulia, serta keterampilan yang diperlukan dirinya, masyarakat, bangsa dan negara (Pasal $1 \mathrm{UU}$ No. 20 Tahun 2003). Berdasarkan defenisi ini, maka pendidikan harus mampu menjadi agen utama dalam mengemban tugas peningkatan kualitas sumber daya manusia Indonesia. Meningkatnya kualitas pendidikan ditandai dengan menurunnya tingkat pendidikan terendah, meningkatnya partisipasi pendidikan dan meningkatnya jumlah tenaga kerja dengan pendidikan yang semakin tinggi.

Perkembangan global menuntut seluruh negara termasuk Indonesia memiliki kesiapan menghadapi pasar global dengan persaingan diberbagai bidang. Pembangunan dibidang pendidikan harus menjadi penggerak utama dalam peningkatan kualitas sumber daya manusia. Tuntutan globalisasi harus diantisipasi oleh 
dunia pendidikan Indonesia dengan mengintegrasikan humanbeing dan technobeing atau keterpaduan sains dan agama. Pendidikan dengan penanaman nilai, pendekatan budaya, pemberdayaan kompetensi (pengetahuan dan skill) dan keterpaduan dengan kebijakan politik (Dewi, 2019). Sehingga sumber daya manusia Indonesia siap menghadapi persaingan yang semakin ketat dengan negara-negara lain. Bagaimana dengan pendidikan agama Kristen di negeri ini? Apa yang bisa disumbangkan oleh dunia pendidikan agama Kristen dalam ikut meningkatkan sumberdaya manusia Indonesia?

\section{METODE PENELITIAN}

Penelitian ini dilakukan dengan kajian pustaka (Hamzah, 2020, p. 21) yang sepenuhnya mencari sumber-sumber literatur seperti buku-buku, jurnal-jurnal hasil penelitian yang berkaitan dengan topik penelitian dan beberapa artikel serta sumber berita untuk mendapatkan gambaran dan kondisi terkini mengenai sumber daya manusia Indonesia (Zed, 2008, p. 1). Penulis mengumpulkan kemudian mengolah data dan teori dari berbagai literatur. Penulis tidak mengumpulkan data dari situasi lapangan secara langsung. Data yang dipakai dalam tulisan ini adalah data sekunder, dimana penulis memperoleh data dari tangan kedua bukan asli dari nara sumber pertama di lapangan.

Bagian pertama tulisan membahas pentingnya kualitas sumber daya manusia dan memberikan gambaran tentang kondisi sumber daya manusia di Indonesia. Bagian kedua membahas tentang bagaimana pendidikan agama Kristen bertujuan untuk mendidik peserta didik agar memberi dampak kepada dunia berdasarkan panggilannya dengan berlandaskan kehidupan spiritualnya. Bagian ketiga dari tulisan akan membahas bagaimana sebaiknya pendidikan agama Kristen dirumuskan dan diimplementasikan agar tetap relevan dengan perkembangan zaman dan memberi kontribusi positif dalam membangun kualitas sumber daya manusia.

\section{HASIL DAN PEMBAHASAN}

\section{Sumber Daya Manusia Indonesia dan Tantangan Global}

Hasil sensus penduduk 2020 yang dipublikasikan oleh BPS menyatakan bahwa penduduk Indonesia didominasi oleh generasi z yaitu mereka yang berusia antara 8 tahun s/d 23 tahun atau mereka yang lahir antara tahun 1997 s/d 2012 sebesar 27,94\%. (Badan Pusat Statistik, n.d.). Dari rentang usia yang diberikan, maka dapat diperkirakan bahwa sebagian 
besar dari mereka adalah penduduk Indonesia yang masih bersekolah di sekolah dasar, sekolah menengah dan sedang kuliah di perguruan tinggi. Jika ditambah dengan generasi post $\mathrm{z}$, yaitu mereka yang berusia 7 tahun ke bawah sebesar 10,88\%, maka terdapat $\quad 38,82 \%$ dari $\quad 270.200 .000$ penduduk Indonesia atau berjumlah 104.891.640 jiwa penduduk Indonesia yang masuk dalam usia sekolah dari jenjang pendidikan anak usia dini sampai perguruan tinggi. Jumlah penduduk yang besar ini menjadi tanggungjawab bidang pendidikan untuk mendidik mereka menjadi sumber daya manusia Indonesia yang memberi kontribusi positif dalam kemajuan bangsa.

Setahun sebelumnya atau pada Februari 2019, BPS menyatakan bahwa jumlah angkatan kerja Indonesia sebanyak 136,18 juta orang. Namun angkatan kerja tersebut masih didominasi dengan penduduk bekerja yang berpendidikan SD ke bawah sebesar 50,40 juta (40,51\%), lulusan SMP sebanyak 22,97 juta orang $(17,75 \%)$, lulusan SMA sebanyak 23,10 juta orang $(17,86 \%)$ dan lulusan SMK sebanyak 14,63\% (11,31\%). Sedangkan angkatan kerja lulusan perguruan tinggi sebanyak 16,26 juta (12,57\%) dengan 3,65 juta diantaranya lulusan diploma dan 12,61 juta lulusan Universitas (STATISTIK, 2019).

Peneliti Senior Puslit Kependudukan Lembaga Ilmu Pengetahuan
Indonesia (LIPI) Titik Handayani menyatakan bahwa tenaga kerja Indonesia yang didominasi mereka yang hanya sekolah sampai SD dan 90 persennya terkategori tidak memiliki keterampilan khusus. Menurutnya, rendahnya pendidikan dan tak terampilnya tenaga kerja Indonesia berpengaruh pada minimnya tingkat produktivitas. "Produktivitas tenaga kerja hanya $10,3 \%$ dari produktivitas Singapura. Jauh di bawah tingkat produktivitas tenaga kerja Malaysia sebanyak $36,2 \%$, serta Thailand $16,7 \%$ (Kualitas Tenaga Kerja Indonesia Masih Rendah | Republika Online, n.d.). Dari kedua data di atas dapat kita lihat bahwa produktivitas tenaga kerja Indonesia yang tertinggal dibandingkan negara-negara lain di ASEAN disebabkan oleh rendahnya tingkat pendidikan tenaga kerja Indonesia.

Laporan APO (Asian Productivity Organization) Productivity Databook 2019 menyebutkan bahwa produktivitas tenaga kerja Indonesia berada di posisi 13 dari 24 negara di Asia, dengan level produktivitas 21 persen atau senilai USD 26 ribu, atau sekitar Rp. 364,7 juta (asumsi kurs Rp. 14.027). Tertinggal dengan Malaysia di posisi 8, Srilanka di posisi 9 dan Mongolia di posisi 10. APO sendiri adalah suatu organisasi antar pemerintahan regional Asia-Pasifik yang berdiri tahun 1961 (Liputan6.com, Jakarta, 30 Okt 2019) (Produktivitas Pekerja Indonesia Di Asia 
Urutan Berapa? - Bisnis Liputan6.Com, n.d.). Sekretaris Jenderal Kementerian Ketenagakerjaan, Anwar Sanusi, pada 13 November 2020 menyatakan persentase produktivitas tenaga kerja Indonesia berada di angka 74,4\%. Berada di bawah rata-rata ASEAN yakni $78,2 \%$. Indonesia berada di bawah negara-negara tetangga seperti Filipina $(86,3 \%)$, Singapura $(82,7 \%)$, Thailand $(80,1 \%)$, dan Vietnam $(80 \%)$, Laos (76,7\%) dan Malaysia (76,2\%) (Produktivitas Tenaga Kerja Indonesia Di Bawah Rata-Rata ASEAN - Medcom.Id, n.d.). Rendahnya produktivitas tenaga kerja Indonesia menjadi keprihatinan di tengah tantangan globalisasi. Dimana perkembangan global memaksa kesiapan kita menghadapi persaingan global dalam berbagai bidang yang menuntut kualitas sumber daya manusia yang unggul dan selalu siap dengan berbagai perubahan yang terjadi. Bahkan perkembangan teknologi di abad 21 dimana laju perubahan sangat cepat, kemajuan dan penemuan berada di masa keemasannya, ternyata juga "memaksa" manusia bersaing dengan kecerdasan buatan yang diciptakan manusia itu sendiri (Bonde 2020).

Leni Rohida dalam penelitiannya menyatakan bahwa era industri 4.0 memberikan peluang sekaligus tuntutan kepada sumber daya manusia agar memiliki kompetensi menggunakan teknologi digital untuk mewujudkan pabrik cerdas (smart factories) seperti salah satunya Internet $O f$ Thinks (IOT). Ditambah dengan bonus demografi yang dialami maka tidak ada pilihan bagi sumber daya manusia Indonesia untuk meningkatkan kompetensi agar tetap "eksis", berdaya dan terus maju di zaman revolusi industri 4.0 yang serba otomatis, robotic dan tekhnologi mutakhir (Rohida, 2018). Hal senada diungkapkan oleh Ika Ruhana, bahwa menghadapi persaingan global pengembangan sumber daya manusia harus menjadi prioritas utama, agar tenaga kerja memiliki sifat proaktif dan inovatif untuk mengelola perubahan baik dalam bidang politik, ekonomi, sosial, hukum, teknologi dan lainlain. Dalam perubahan yang serba cepat, manusia harus terus memperluas dan mempertajam pengetahuannya dan mengembangkan kreativitasnya untuk terus berinovasi. Kemampuan memperluas jaringan (social networking) dan soft kapital yang menitikberatkan kepada etika dan karakter juga menjadi nilai penentu untuk mengukur kualitas seseorang (Ruhana, 2012).

Jika pada masa-masa sebelumnya, permasalahan sumber daya manusia disebabkan oleh perkembangan jumlah penduduk yang besar namun perkembangan ekonomi yang lambat atau sebaliknya (Basir, 2001). Maka pada masa sekarang permasalahan sumber daya manusia dipengaruhi kuat oleh globalisasi 
dan kemajuan teknologi. Perubahan yang sangat cepat dalam satu dasawarsa terakhir menyebabkan terjadinya disruption yang sangat cepat dalam segala aspek kehidupan. Namun tantangannya bukan hanya pada disruption itu sendiri, melainkan pada efficiency innovation yaitu inovasi yang berdampak kepada pemangkasan biaya terutama pemangkasaan secara masif pada biaya penggunaan tenaga manusia yang dianggap fixed cost yang membebani. Efficiency innovation menambah keuntungan perusahaan, dimana keuntungan tersebut kemudian dipakai untuk menghasilkan inovasi baru. Maka terjadilah Efficiency innovation yang terus menerus dan mengerakkan perubahan yang tidak mudah diprediksi oleh kebanyakan orang. Namun perubahan tersebut harus diantisipasi agar mampu untuk terus bertahan (Kasali, 2017). Manusia memang menghadapi krisis pada setiap zaman dan selalu punya cara untuk mengatasinya. Namun selalu saja ribuan orang menjadi korban dalam prosesnya, yaitu mereka yang gagal beradaptasi karena kondisi internal yang tidak sesuai dengan tuntutan perubahan dan tentu karena cara berpikirnya (Kasali, 2017). Mereka yang tidak mampu bertahan adalah mereka yang memiliki cara berpikir yang kurang adaptif terhadap perubahan zaman. Lemahnya kemampuan beradaptasi disebabkan lemahnya kemampuan menganalisa dan mengenali perubahan di sekitarnya yang pada akhirnya membuatnya tidak melakukan inovasi apapun. Kemampuan berpikir masyarakat maupun perseorangan sangat dipengaruhi oleh pendidikan yang di dapat, baik secara informal, nonformal maupun formal.

Dalam konteks rendahnya kualitas sumber daya manusia Indonesia dan tantangan perkembangan global, pendidikan agama Kristen menghadapi tantangan yang tidak mudah, namun sekaligus memiliki peluang untuk menjadi berkat bagi peradaban manusia. Pendidikan agama Kristen selama ini telah ikut andil dalam pengembangan sumber daya manusia. Karena telah melakukan tugas dalam tanggungjawab moral untuk mampu mengubah peserta didik dari segi kognitif, afektif dan psikomotorik (Mardiharto, 2019). Kontribusi Pendidikan agama Kristen dalam membangun sikap, membangun kemampuan kognitif, dan membangun kemampuan psikomotorik peserta didik merupakan kontribusi besar pendidikan agama Kristen bagi pengembangan kualitas sumber daya manusia di Indonesia.

\section{Pendidikan Agama Kristen Ditengah Perubahan Zaman}

Pendidikan di sekolah bahkan pendidikan agama tidak boleh menciptakan jurang pemisah antara hal-hal yang 
dipandang ilmu akademis dengan dunia nyata yang dihadapi sehari-hari. Karena tujuan pendidikan di sekolah adalah membantu para siswa belajar tentang dunia dan peran serta tugas-tugas mereka di dunia yang mereka diami (Richard 2015). Lebih lanjut Richard J. Edlin menyatakan bahwa karakteristik khas dalam pendidikan Kristen adalah: pertama-tama melibatkan upaya menantang peserta didik memuliakan Kristus sebagai Tuhan atas semua ciptaan; kedua, membawa peserta didik untuk melihat kepada dunia dan tempat kita serta tugas-tugas panggilan di dunia (Richard, 2015) Jadi jelas bahwa Pendidikan Agama Kristen bukanlah bidang pelajaran yang hanya menekankan kepada hal-hal spiritualitas atau penanaman doktrin agama Kristen saja, melainkan bagaimana spiritualitas yang berlandaskan kepada Sang Firman menjadi sumber pedoman dan inspirasi untuk memberi kontribusi positif kepada kehidupan bermasyarakat. Pendidikan agama Kristen harus mengajarkan dogmatika iman Kristen sekaligus secara terbuka membahas masalah-masalah sosial dalam masyarakat yang menjadi panggilan bagi umat Kristen untuk menjadi bagian solusi dari masalahmasalah tersebut.

Meskipun memiliki kekhasan sendiri, sebenarnya pendidikan agama Kristen ikut ambil bagian dalam pendidikan yang bersifat politis dan umum (Thomas
2011). Aktivitas politis yang dimaksud adalah upaya sadar, terencana dan sistematis untuk mempengaruhi peserta didik agar mereka menjalani hidup sesuai dengan nilai-nilai dan tujuan iman Kristen di tengah masyarakat dengan berbagai nilai hidup, kebutuhan dan tuntutannya yang terus berubah dari zaman ke zaman. Jadi pendidikan Kristen tidak akan pernah terlepas dari dinamika masyarakat atau peradaban manusia. Lebih jauh Groome menguraikan bahwa tujuan pendidikan agama Kristen adalah memampukan orangorang untuk hidup sesuai iman Kristen, yaitu hidup bagi Kerajaan Allah, berjuang menghadirkan Kerajaan Allah yang memperbaharui seluruh ciptaan terutama manusia (G. H. Thomas, 2011). Pendidikan agama Kristen harus memberdayakan peserta didik untuk mampu terus menerus memahami dan merespon kehendak Allah sekaligus merespon kondisi dunia yang terus berubah dengan menawarkan solusi kreatif dan relevan dengan berlandaskan nilai-nilai Kerajaan Allah.

Pendidikan agama Kristen adalah usaha sadar, sistematis dan berkesinambungan baik yang menekankan usaha kepada pencarian yang transenden, kehendak-Nya dan pemberlakuan kehendak-Nya dalam kehidupan konkrit dimana Alkitab sebagai dasar untuk membentuk masa depan sesuai visi Allah berdasarkan warisan masa lampau dan 
tindakan kreatif masa kini, sehingga mempengaruhi kehidupan religius peserta didik secara individual dan bersikap ketika menjalani kehidupan dalam konteks masyarakatnya (Nuhamara, 2007). Membentuk masa depan sesuai visi Allah melalui tindakan kreatif masa kini sesuai konteks masyarakat menjadikan proses pendidikan agama Kristen akan selalu dinamis dan mempengaruhi sekaligus dipengaruhi oleh perkembangan peradaban manusia.

Pendidikan agama Kristen harus mampu menolong orang Kristen belajar dari masa lalu dengan menghargai warisan iman yang menghasilkan sukacita, pertobatan dan pembaharuan; hidup dalam realita di masa kini dengan mempelajari ilmu sosial dengan kepedulian untuk mengantisipasi kehidupan akan masa depan di dalam Tuhan (Robert 2013). Bahkan perkembangan keilmuan seperti penemuan tingkat perkembangan manusia membantu pendidik Kristen untuk memahami kompleksnya ciptaan yang bernama manusia dan merumuskan tujuan, metode dan strategi mengajar sesuai dengan tingkat perkembangan manusia pada kelompok usia tertentu (Michael 2012). Perubahan zaman harus dilihat sebagai peluang bagi pendidikan agama Kristen untuk mempengaruhi dunia dengan Kasih Allah yang selalu tersedia melimpah bagi umat manusia dari zaman ke zaman. Maka perubahan zaman berupa perkembangan keilmuan, penemuan tekhnologi baru bahkan kecerdasan buatan harus dilihat sebagai "alat bantu" bagi pendidikan iman Kristen untuk lebih efektif sekaligus sebagai bahan reflektif untuk tetap berpegang kepada Kebenaran agar tetap relevan ditengah dunia yang terus berubah dengan cepat.

Pendidikaan agama Kristen sebagai salah satu fungsi gereja yang amat penting harus mempertimbangkan eksistensi masa depan gereja di tengah dunia yang terus berubah dalam menyusun isi dan strategi pembelajaran. Pendidikan agama Kristen harus mampu memberi pengaruh kepada peserta didik untuk bersikap dan memberi respon secara benar sekaligus memberi dampak dalam masyarakat global dengan segala perubahan dan permasalahan di dalamnya (Saputra \& Novalina, 2020). Sejarah membuktikan bahwa dunia pendidikan Kristen terlibat proaktif mengembangkan dunia pendidikan modern yang menghasilkan peradaban di Barat, Eropa dan Amerika yang mempengaruhi benua lain dimana iman Kristen diwartakan (Mawikere, 2020). Dalam perkembangan peradaban manusia ternyata pendidikan agama Kristen memiliki tempat dan perannya sendiri, bahkan telah memberikan kontribusi penting. 
Peran Pendidikan Agama Kristen dalam Peningkatan Kualitas Sumber Daya Manusia

Pendidikan agama Kristen berperan aktif dalam upaya peningkatan kualitas sumber daya manusia. Bahkan bertanggungjawab meletakkan dasar moral bagi perkembangan kognitif, afektif dan psikomotorik peserta didik (Mardiharto, 2019). Tulisan ini menyetujui pendapat bahwa pendidikan agama Kristen harus menerapkan nilai-nilai dan prinsip yang sejalan dengan teladan Yesus, dimana pendidikan Kristen dibangun dari kehidupan Yesus (Bonde, 2020). Pendidikan agama Kristen harus merupakan pendidikan yang berpusat kepada Allah (Louis and Cornelius 2018). Isi pendidikan Kristen harus menekankan panggilan memberitakan Injil dan bekerja demi damai sejahtera atau shalom (Nicholas, 2014, p. 49). Pendidikan harus menekankan pembentukan karakter yang terdiri dari tiga bagian utama, yaitu pengetahuan moral, perasaan moral dan tindakan moral (Thomas 2019). Dalam konteks pendidikan agama Kristen, maka pembentukan karakter harus menjadikan karakter Kristus sebagai tujuan dan teladan. Nilai-nilai yang berpusat kepada teladan hidup Yesus, panggilan memberitakan injil untuk menghadirkan shalom serta pembentukan karakter peserta didik yang berlandaskan Firman Tuhan harus terus menjadi isi pendidikan agama Kristen yang diselenggarakan. Meniadakan salah satu dari hal-hal ini menyebabkan terjadinya pengingkaran terhadap hakikat dan tujuan dari pendidikan agama Kristen itu sendiri.

Dalam rangka mewujudkan kontribusi aktif pendidikan agama Kristen dalam peningkatan sumber daya manusia, maka pendidikan agama Kristen dituntut mengalami perubahan mendasar dalam kebijakan dan implementasi di lapangan. Pendidikan agama Kristen tidak bisa lagi diambil berdasarkan kepentingan gereja saja tetapi harus dilakukan dengan melihat perkembangan global. Pendidikan agama Kristen harus ikut andil dalam menghasilkan sumber daya manusia yang memiliki jiwa kepemimpinan, kemampuan berinovasi, membangun jaringan (networking) dan penguasaan teknologi, mengingat keempat hal tersebut ikut menentukan kemajuan suatu bangsa. Beberapa hal yang dapat dilakukan untuk meningkatkan kontribusi dalam meningkatkan kualitas pendidikan agama Kristen adalah:

Pertama, memperkuat pendidikan agama Kristen dalam keluarga sebagai peletakan dasar karakter, kecerdasan emosional, kreatifitas dan kompetensi dasar bagi anak-anak. Kegiatan pendidikan terlebih pendidikan agama Kristen harus dimulai dirumah, meskipun rumah bukan satu-satunya tempat untuk berjumpa 
dengan hal-hal yang transenden (G. H. Thomas, 2011). Pendidikan informal dalam keluarga memberi pengaruh mendalam bagi perkembangan peserta didik baik dalam pertumbuhan spiritual, perkembangan psikis dan perkembangan kemampuan kognitif dan karakter. Cara orangtua memperlakukan anaknya berakibat mendalam dan permanen dalam diri anak (Goleman 1997). Beberapa contoh pendidikan iman dalam keluarga yang dicatat oleh Alkitab dapat kita lihat pada kehidupan Samuel, Timotius dan banyak teladan iman lain. Benih iman dan kepemimpinan Samuel dimulai dalam pendidikan iman dan ketaatan Hanna dan Elkana sebagai orangtua yang diteladankan sejak awal kehidupan Samuel (Prabowo, 2020). Demikian juga benih iman dan penggilan melayani Timotius yang diakui Paulus berasal dari kehidupan iman neneknya Lois dan Eunike ibunya (2 Timotius 1:5). Demikian pula pendidikan agama Kristen yang dilakukan dalam keluarga akan diserap oleh seorang anak, membekas secara mendalam dan mempengaruhi hidupnya. Menurut Howard Gardner, kecerdasan emosional dalam diri seseorang mulai terbentuk sejak hari-hari pertama dalam kehidupannya. Maka betapa beruntungnya bayi-bayi yang lahir dengan orangtua yang memiliki kecerdasan emosi. Pendidikan informal dalam keluarga mengambil peranan penting bagi pembentukan dasar dan perkembangan kecerdasan emosional seseorang yang akan ikut menentukan keberhasilannya dalam kehidupannya di masa yang akan datang. Kemampuan non kognitif seperti kemampuan meregulasi diri, pengendalian diri, kemampuan mengelola daya tahan (persistensi), menghadapi tekanan, menunda kenikmatan, ketekunan menghadapi kejenuhan, dan kecenderungan menjalankan rencana adalah elemenelemen dari kecerdasan emosional. Pendidikan agama Kristen harus menolong sebanyak mungkin keluarga Kristen agar memiliki pengetahuan dan keterampilan yang cukup dapat memuridkan anak-anak mereka di dalam konteks kehidupan keluarga. Gereja dan sekolah dapat memberikan pengetahuan dan keterampilan yang diperlukan keluarga-keluarga Kristen melalui seminar, pelatihan dan pendampingan. Sehingga setiap keluarga dapat menjadi "wadah" pendidikan iman Kristen bagi anak-anaknya.

Kedua, memperkuat pendidikan anak usia dini Kristen baik formal maupun informal. Pendidikan untuk menghasilkan sumber daya manusia yang unggul harus dimulai sejak usia dini melalui pendidikan informal dalam keluarga dan dilanjutkan dengan pendidikan anak usia dini melalui PAUD atau sekolah Taman Kanak-Kanak, kemudian ke jenjang pendidikan dasar sampai pendidikan menengah. Program 
wajib belajar 9 tahun seharusnya diubah menjadi program wajib belajar 18 tahun, yaitu sejak lahir melalui pendidikan informal dalam keluarga sampai dengan usia 18 tahun atau saat anak-anak lulus sekolah menengah atas atau kejuruan. Gereja dan sekolah Kristen harus hadir dalam memperkuat pendidikan anak usia dini yang mengutamakan isi dan proses pembelajaran yang sesuai dengan perkembangan anak dan fokus kepada perkembangan karakter dan kreatifitasnya.

Menurut Direktorat Pembinaan Pendidikan Anak Usia Dini (PAUD) Kementerian Pendidikan Nasional, pada tahun 2018, angka partisipasi rata-rata anak usia dini yang terlayani baru sekitar 74,3\%. Namun masih terdapat kesenjangan angka partisipatif antar daerah khususnya di daerah pedesaan. Masih ada sekitar 35,7 \% anak usia dini pada 23.737 desa atau berjumlah 6.536.229 anak usia dini yang belum mendapat akses layanan Pendidikan anak usia dini di Indonesia (Berita | Percepatan Pembangunan PAUD Lewat Dialog Nasional Kebijakan, n.d.). Pada bulan April Tahun 2019 dilansir terdapat 23 ribu desa dari 83 ribu desa di Indonesia yang belum memiliki pendidikan anak usia dini (23 Ribu Desa Belum Memiliki Akses Satu Desa Satu PAUD - Siedoo, n.d.). Dari data di atas, dapat disimpulkan bahwa gereja dan sekolah Kristen masih memiliki peluang besar untuk terlibat aktif dalam perluasan akses pendidikan anak usia dini dan peningkatan kualitasnya. Pendidikan anak usia dini di Indonesia merupakan salah satu ladang pelayanan yang sangat besar bagi gereja dan sekolah Kristen.

Ketiga, meningkatkan kualitas tenaga pendidik agama Kristen baik di gereja maupun di sekolah. Peningkatan kualitas tenaga pendidik dapat dilakukan melalui pelatihan bagi guru-guru agama yang sudah mengajar dan peningkatan kualitas pendidikan tinggi Kristen yang menghasilkan calon-calon guru agama Kristen. Sehingga semakin banyak sekolah dan gereja memiliki tenaga pendidik agama Kristen berkualitas yang bukan sekedar mengajar tetapi memiliki keteladanan hidup sekaligus kreatif dan inovatif dalam mengajar.

Terbentuknya sumber daya mansuia berkualitas sebagai out put pendidikan diawali dari kualitas guru. Karena kualitas pembelajaran dan perbaikan mutu layanan pendidikan agama Kristen sekolah bergantung kepada guru yang mengajar. Guru berperan sebagai ujung tombak dalam peningkatan kualitas peserta didik. Tugas guru agama Kristen meliputi mendidik, mengajar dan melatih. Mendidik berarti meneruskan dan mengembangkan nilainilai hidup. Mengajar berarti meneruskan dan mengembangkan ilmu pengetahuan dan tekhnologi. Sedangkan melatih berarti mengembangkan ketrampilan-ketrampilan 
pada siswa. Guru agama Kristen merupakan "orangtua kedua" bagi para peserta didiknya. Sekolah dan gereja adalah tempat pendidikan kedua setelah keluarga. Karena itu seorang guru harus menjadi orangtua yang penuh kasih sayang sekaligus menjadi teman, tempat mengadu bagi para peserta didik untuk mengutarakan perasaannya. Memahami peserta didik, mengenali potensi dan bakatnya, memotivasi serta mendampingi peserta didik pada masa-masa sulit mereka dalam perjalanan menjadi seseorang yang secara aktif mengembangkan potensi dirinya untuk memiliki kekuatan spiritual, pengendalian diri, kepribadian, kecerdasan, karakter, serta keterampilan yang diperlukan dirinya.

Keempat, mengembangkan kurikulum yang memberdayakan dan berpusat kepada peserta didik. Kurikulum Pendidikan agama Kristen yang sudah ada harus diperkaya dengan isi pembelajaran yang berorientasi kepada penemuan dan pengembangan potensi para peserta didik sesuai dengan desain Tuhan atas diri mereka masing-masing. Selain itu kurikulum Pendidikan agama Kristen yang membangun karakter sekaligus kemampuan kognitif dalam level high order thinking, yaitu kurikulum pendidikan yang menyeimbangkan antara pengembangan afektif, kognitif dan skill. Adapun rancangan pendidikan komprehensif dan berkelanjutan yang diusulkan adalah sebagai berikut:

a. Basic development, usia 0 - 2 tahun, berupa program penguatan pendidikan informal dalam keluarga untuk membangun kecerdasan emosional anak. Revitalisasi POSYANDU sebagai perpanjangan tangan pemerintah dapat menjadi akses bagi penguatan pendidikan informal dalam keluarga bahkan sejak anak-anak masih dalam kandungan ibunya.

b. Character development, usia $2-6$ tahun, berupa layanan pendidikan anak usia dini yang menekankan kepada pembentukan karakter anak dan kreatifitas melalui berbagai sarana permainan. Pembaharuan yang dimulai dengan perubahan paradigma layanan pendidikan anak usia dini, pemberdayaan guru-guru, perbaikan kurikulum dan pembenahan sistem pengelolaan PAUD menjadi hal mendesak untuk dilakukan.

c. Leadership development, usia 7- 12 tahun, berupa layanan pendidikan sekolah dasar, dan menengah pertama yang menekankan ranah afektif, kognitif dan psikomotorik secara seimbang. Kurikulum yang berdasarkan filosofi penemuan dan pengembangan kecerdasan majemuk (multiple intelegence). 
d. Kompetensi development, usia 13 - 18 tahun, berupa layanan pendidikan sekolah menengah umum atau kejuruan yang menekankan kompetensi sesuai kecerdasan yang dimiliki masingmasing peserta didik (dasar filosofi multiple intelegence), kemampuan entrepreuner, membangun jejaring dan penguasaan teknologi.

Kelima, mengembangkan sistem pembelajaran yang memberdayakan dan melatih peserta didik menjadi manusia pembelajar. Proses pembelajaran yang bukan hanya menolong peserta didik untuk menghafal, memahami dan mampu mengaplikasikan materi pembelajaran dalam kehidupan sehari-hari, namun proses pembelajaran yang mampu memberi rangsangan dan membangkitkan kemampuan menganalisa, mengevaluasi dan berpikir kreatif dalam diri peserta didik. Pendidikan agama Kristen baik dalam keluarga, dalam gereja maupun di sekolah harus memperhatikan setidaknya tiga hal penting dalam implementasi pendidikan agama Kristen, yaitu:

1. Pendidikan agama Kristen harus memandang peserta didik sebagai pribadi dengan potensi besar dalam dirinya, bahkan layak disebut potensi ilahi. Karena dalam diri peserta didik, Allah telah meletakkan potensi untuk mengalahkan kemiskinan, ketidakadilan, sakit penyakit dsb
(Mazmur 8:3). Para pendidik agama Kristen harus melihat peserta didik sebagai pribadi dengan "harta karun" potensi yang harus dikembangkan untuk diaktualisasikan bagi usahausaha kemanusiaan. Dalam diri peserta didik terdapaat kecerdasan majemuk yang harus diidentifikasi dan dikembangkan. Proses pendidikan harus harus menolong peserta didik mengindentifikasi dan mengembangkan kecerdasan yang dimilikinya (Gardner 2013). Di samping menanamkan berbagai kecerdasan yang berbeda-beda pada setiap pribadi, Allah membentuk setiap peserta didik unik dengan SHAPE-nya masing-masing, yaitu sprituial gift (karunia rohani), heart (keinginan hati atau hasrat), abilities (kemampuan), personality (kepribadian) dan experiences (pengalaman hidup yang unik dan personal). Semua itu dibuat Allah berdasarkan tujuan penciptaan Allah kepada masing-masing pribadi (Rees 2006). Dengan demikian, proses pendidikan agama Kristen ibarat menggali harta terpendam yaitu potensi dalam diri peserta didik untuk teraktualisasi keluar.

2. Pendidikan agama Kristen harus meningggalkan pembelajaran bercorak indoktrinasi dan melakukan pembelajaran transformatif yang 
mengubah hidup melalui proses penemuan kebenaran oleh si pembelajar. Kemudian membawa mereka dalam proses pendidikan progresif yang akan membawa mereka tampil ke publik untuk menebarkan berita "keselamatan sosial" dengan mengupayakan kesejahteraan sosial dengan memerhatikan dan memenuhi kebutuhan hidup masyarakat (Tambunan, 2020). Proses pembelajaran indoktrinasi yang "menuangkan" pengetahuan tentang iman Kristen harus digantikan dengan proses pendidikan yang memerdekakan. Pendidikan yang sejati tidak dilaksanakan oleh pendidik untuk peserta didik, atau oleh pendidik tentang peserta didik, melainkan oleh pendidik bersama peserta didik dengan dunia sebagai medianya, sehingga keduanya semakin "memanusia" baik secara etik, estetika maupun spiritual (Freiree 1985). Pembelajaran dalam pendidikan agama Kristen harus diselenggarakan sedemikian rupa sehingga peserta didik mengalami proses penemuan makna dari materi pembelajaran yang kemudian menjadi prinsip-prinsip yang dimiliki oleh siswa (Slavin 2009). Pembelajaran inquiri dapat menjadi alternatif dalam strategi pembelajaran agama Kristen. Karena inquiri menekankan peran aktif peserta didik untuk terlibat penuh dalam proses berpikir kritis dan analistis untuk mencari dan menemukan sendiri jawaban dari permasalahan yang dihadapi (Abdul Majid 2013). Proses belajar bukanlah proses indoktrinasi, melainkan merupakan suatu proses penemuan. Sehingga perjumpaan peserta didik dengan Sang Transenden adalah sebuah pengalaman hidup yang terserap dalam memori terdalam dan menjadi pengetahuan yang terus menerus disempurnakan dalam perjalanan hidup siswa. Perjumpaan dengan Sang Transenden bukan berdasarkan apa kata guru agama, pendeta atau pembina rohani melainkan merupakan sebuah proses penemuan pengetahuan yang berubah menjadi pengalaman dalam kehidupan peserta didik dan menjadi "pewahyuan" secara pribadi bagi peserta didik namun tetap teruji oleh Cerita Iman warisan masa lampau. Merujuk pengalaman Ayub dalam perjumpaannya dengan Allah melalui pengalaman hidupnya (Ayub 42 :5). Jika proses pembelajaran "agama" yang dialami generasi Kristen adalah suatu upaya sadar, sistematis dan berkesinambungan yang menyeimbangkan penyerapan pengetahuan iman melalui proses penemuan pengetahuan iman (bukan sekedar indoktrinasi) dengan 
pengalaman iman dalam praktek kehidupan sehari-hari, maka religiusitas peserta didik terbentuk lebih kuat.

3. Pendidikan agama Kristen harus terbuka pada proses belajar secara kritis melalui pembiasaan high order thinking atau berpikir tingkat tinggi dalam konsep taksonomi Bloom (T. G. Ratumanan and Imas Rosmiati, 2020). Para pendidik agama Kristen harus terbuka dan membawa peserta didik melakukan proses berpikir analisis, evaluatif dan kreatif thinking dan tidak berhenti pada proses menghafal, memahami dan menerapkan pengetahuan iman Kristen. Tentu saja pembelajaran dengan pembiasaan high order thinking disesuaikan dengan tingkat perkembangan peserta didik. Bloom dkk menyatakan bahwa taksonomi ini juga berlaku bagi ranah afektif dan ranah psikomotorik, bukan hanya untuk ranah kognitif semata (W.S. Winkel S.J. 2014). Jika dalam pembelajaran sains saja, keterampilan berpikir tingkat tinggi dapat dipakai untuk mengembangkan karakter, dimana proses berpikir tinggi kemudian menjadi habits of mine yang dijabaarkan sebagai value, inclination, sensitivity, capability dan commitment untuk berpikir dan berperilaku cerdas dalam berbagai situasi (Rustaman,
2011) terlebih dalam pembelajaran PAK.

Dalam proses pembelajaran agama Kristen, para pendidik dapat mengajak peserta didik menganalisa kehidupan para pahlawan iman, menganalisa konteks kehidupan umat Allah serta keberhasilan melakukan kehendak Allah atau kegagalan dan kejatuhan umat-Nya, Menganalisa bagaimana Allah hadir dan terlibat dalam kehidupan umat-Nya, Mengevaluasi bagaimana para tokoh Alkitab dan umat Allah memberikan respon mereka terhadap keterlibatan Allah dalam hidup umat-Nya. Menganalisa dan mengevaluasi bagaimana Gereja merespon kehendak-Nya pada masa kini. Dan akhirnya secara kreatif menemukan cara-cara terbaru menemukan Allah dan kehendak-Nya dan cara-cara kreatif untuk menghadirkan Kerajaan Allah dalam masyarakatnya. Proses berpikir analisis, evaluatif dan kreatif thinking akan melatih peserta didik memiliki kekritisan berpikir namun juga memiliki kemampuan problem solving dan kemampuan mencipta. Dengan demikian peserta didik memiliki modal utama dalam dirinya untuk mengembangkan kemampuan berinovasi. Peserta didik juga memiliki kemampuan mengambil sikap terhadap suatu masalah berdasarkan Alkitab karena mampu menjembatani perbedaan zaman, budaya dan konteks masa Alkitab ditulis dengan 
zaman, budaya dan konteks masa kini melalui proses menganalisa, mengevaluasi dan kreatif thinking.

\section{KESIMPULAN}

Tuntutan global dalam perubahan zaman yang sangat cepat dan perkembangan tekhnologi menuntut kualitas sumber daya manusia unggul yang mampu berinovasi untuk dapat terus bertahan dan memberi perubahan. Pendidikan agama Kristen adalah pendidikan menyeluruh yang menjadikan pengembangan peserta didik pada ranah afektif, psikomotorik dan kognitif sebagai tujuan pembelajaran. Pendidikan agama Kristen merupakan proses belajar untuk membangun kesadaran kepada peserta didik bahwa diri mereka adalah anak Allah yang memiliki sejumlah potensi dalam dirinya. Proses pembelajaran agama Kristen merupakan proses menolong peserta didik untuk menemukan, mengembangkan dan mengaktualisasikan potensi tersebut.

Pendidikan agama Kristen dapat semakin memberikan kontribusi nyata bagi upaya pengembangan sumber daya manusia di Indonesia melalui revitalisasi pendidikan agama Kristen dalam keluarga, menambah kualitas dan kuantitas pendidikan anak usia dini Kristen, meningkatkan kualitas pendidik agama
Kristen baik di sekolah maupun di gereja, memperkaya kurikulum pendidikan agama Kristen dengan kurikulum yang memberdayakan peserta didik untuk menemukan dan mengembangka potensi dirinya serta mengubah proses pembelajaran yang merangsang kemampuan peserta didik dalam proses penemuan makna, peningkatan kemampuan berpikir pada level high order thinking.

Tenaga pendidik pada pendidikan agama Kristen harus meninggalkan pola pembelajaran yang bersifat indoktrinasi dan beralih kepada pola pembelajaran inquiry yang mampu membentuk jiwa pembelajar dan membiasakan diri dalam proses problem solving. Dimana proses belajar merupakan proses penemuan ilmu pengetahuan dan makna dari ilmu pengetahuan itu sendiri. Proses pembelajaran agama Kristen juga harus membawa peserta didik kepada tingkat berpikir analisis, evaluatif dan kreatif. Sehingga peserta didik terlatih untuk menyelesaikan masalah melalui proses berpikir kreatif yang mampu menghasilkan produk atau cara-cara baru yang inovatif untuk menyelesaikan suatu masalah atau memberi nilai tambah kepada produk atau cara-cara lama yang sudah ada sebelumnya.

Proses pembelajaran yang berpusat kepada peserta didik melalui penemuan jati diri, proses berpikir kritis dan kreatif dapat 
membawa peserta didik mengalami penemuan pengetahuan iman dan mengalami Allah sendiri namun tetap terhubung dengan kemajuan zaman melalui inovasi yang dihasilkan dari proses berpikir yang kritis dan kreatif. Dengan demikian peserta didik memiliki modal utama untuk terus bertahan dalam perubahan zaman dengan mengenal jati dirinya, menjadi seorang pembelajar dan kemampuan berinovasi.

\section{DAFTAR PUSTAKA}

23 Ribu Desa Belum Memiliki Akses Satu Desa Satu PAUD - Siedoo. (n.d.). https://siedoo.com/berita-19901-23ribu-desa-belum-memiliki-akses-satudesa-satu-paud/

Abdul Majid, M. P. (2013). Strategi Pembelajaran. PT Remaja Rosdakarya.

Badan Pusat Statistik. (n.d.). https://www.bps.go.id/publikasi.html Basir, B. (2001). Manajemen Sumber Daya Manusia Suatu Pendekatan Makro. Bumi Aksara.

Berita | Percepatan Pembangunan PAUD lewat Dialog Nasional Kebijakan. (n.d.).

https://disdikpora.bulelengkab.go.id/i nformasi/detail/berita/percepatanpembangunan-paud-lewat-dialognasional-kebijakan-51
Bonde, I. B. (2020). Kembali ke Akar: Pendidikan Kristen dalam Menghadapi Isu Perubahan Iklim, Perang, dan Keterbatasan Akses Pendidikan. EDULEAD: Journal of Christian Education and Leadership, 1(2), 196-213. https://doi.org/10.47530/edulead.v1i2 .46

Dewi, E. (2019). Potret Pendidikan di Era Globalisasi Teknosentrisme dan Proses Dehumanisasi. Sukma: Jurnal Pendidikan, $\quad 3(1), \quad$ 93-116. https://doi.org/10.32533/03105.2019

Freiree, P. (1985). Pendidikan Kaum Tertindas. LP3ES.

Gardner, H. (2013). Multiple Intelligences. Daras Books.

Goleman, D. (1997). Emotional Intelligence Kecerdasan Emosional. PT Gramedia Pustaka Utama.

Hamzah, A. (2020). Metode Penelitian Kepustakaan Library Research. Literasi Nusantara.

Kasali, R. (2017). Disruption.

Kualitas Tenaga Kerja Indonesia Masih Rendah | Republika Online. (n.d.). https://republika.co.id/berita/ekonomi /makro/15/09/17/nutmxw377kualitas-tenaga-kerja-indonesiamasih-rendah

Louis, B., \& Cornelius, V. T. (2018). Foundations of Christian Education. Penerbit Momentum. 
Madjid, N. (1987). Islam, Kemodernan dan

KeIndonesiaan. Mizan.

Mardiharto, M. (2019). Pembangunan

Sumber Daya Manusia Melalui

Bidang Pendidikan Agama Kristen.

PASCA : Jurnal Teologi Dan

Pendidikan Agama Kristen, 15(2), 28-

32.

https://doi.org/10.46494/psc.v15i2.56

Mawikere, M. C. S. (2020). Book Review:

Desain Pendidikan Karakter:

Konsepsi dan Aplikasinya dalam

Lembaga Pendidikan. EDULEAD:

Journal of Christian Education and

Leadership, 1(2), 232-236.

https://doi.org/10.47530/edulead.v1i2

.49

Michael, A. J. (2012). Foundations Of

Ministry an Introduction to Christian

Education for a new Generation.

Gandum Mas.

Nicholas, W. P. (2014). Mendidik Untuk

Kehidupan Educating For Life.

Penerbit Momentum.

Nuhamara, D. (2007). Pembimbing PAK

Pendidikan Agama Kristen. Jurnal

Info Media.

Prabowo, W. (2020). Peran Elkana dan

Hana terhadap Masa Kecil Samuel:

Tahap Awal Mencetak Pemimpin

Kristen. EDULEAD: Journal of

Christian Education and Leadership,

162-179.

https://doi.org/10.47530/edulead.v1i2
.39

Produktivitas Pekerja Indonesia di Asia Urutan Berapa? - Bisnis Liputan6.com. (n.d.). https://www.liputan6.com/bisnis/read /4099018/produktivitas-pekerjaindonesia-di-asia-urutan-berapa

Produktivitas Tenaga Kerja Indonesia di Bawah Rata-rata ASEAN Medcom.id. (n.d.). https://www.medcom.id/nasional/poli tik/GNlq60gb-produktivitas-tenagakerja-indonesia-di-bawah-rata-rataasean

Prof. Dr. T. G. Ratumanan, M. P., \& Imas Rosmiati, S.Pd, M. P. (2020). PERENCANAAN PEMBELAJARAN. PT Raja Grafindo Persada.

Rees, E. (2006). SHAPE Finding \& Fulfilling Your Unique Purpose for Life. ZONDERVAN.

Richard, E. J. (2015). Hakikat Pendidikan Kristen. BPK Gunung Mulia.

Robert, P. W. (2013). Fondasi Pendidikan Kristen. BPK Gunung Mulia.

Rohida, L. (2018). Pengaruh Era Revolusi Industri 4.0 terhadap Kompetensi Sumber Daya Manusia. Jurnal Manajemen Dan Bisnis Indonesia, $6(1)$ 114-136. https://doi.org/10.31843/jmbi.v6i1.18 7

Ruhana, I. (2012). Pengembangan Kualitas Sumber Daya Manusia vs Daya Saing 
Global. PROFIT : Jurnal Administrasi

Bisnis.

Rustaman, N. (2011). Pendidikan dan Penelitian Sains dalam Mengembangkan Keterampilan Berpikir Tingkat Tinggi untuk Pembangunan Karakter. Prosiding Seminar Biologi, $\quad 8$. https://jurnal.fkip.uns.ac.id/index.php/ prosbio/article/view/748

Saputra, M. P. E., \& Novalina, M. (2020). Tantangan Pendidikan Agama Kristen Di Era Revolusi 4.0 Dan Pasca Kebenaran. Bonafide, 1.

Slavin, R. (2009). Psikologi Pendidikan, Teori dan Praktek, edisi kedelapan. INDEKS.

STATISTIK, B. P. (2019). Berita Resmi Statistik Keadaan Ketenagakerjaan Indonesia Februari 2019, . file://C:/Users/USER/Desktop/Rapat Pimpinan STAK Jan 2021/23.

Keadaan Tenaga Kerja Februari 2019 Sumber Brs Bps Diy.pdf

Tambunan, E. (2020). Pendidikan Progresif

Dan Kaum Urban: Mencari Wajah

Baru Kontribusi Sosial. Edulead: Journal of Christian Education and Leadership, $\quad 1(1), \quad$ 56-76. https://doi.org/10.47530/edulead.v1i1 .27

Thomas, G. H. (2011). Christian Religious Education Pendidikan Agama Kristen. BPK Gunung Mulia.
Thomas, L. (2019). Educating for Character Mendidik untuk Membentuk Karakter. Bumi Aksara. Todaro, M. P. (1983). Pembangunan Ekonomi di Dunia Ketiga. Ghalia.

W.S. Winkel S.J., M. S. (2014). PSIKOLOGI PENGAJARAN. SKETSA.

Zed, M. (2008). Metode Penelitian Kepustakaan. Yayasan Obor Nusantara. 